\title{
Ideal Format the Institution of Social Security Administration to Manage Health Security's Funds in Indonesia
}

\author{
Pujiyono*, Djuwityastuti \\ Department of Law, Sebelas Maret University, Surakarta, Indonesia
}

Copyright (C) 2015 by authors, all rights reserved. Authors agree that this article remains permanently open access under the terms of the Creative Commons Attribution License 4.0 International License

\begin{abstract}
The existing of the Social Security Administration is one manifestation of the nation's goals that is called in Indonesian Constitution, which is to promote the general welfare through health security. But the Social Security Administration in Indonesia, which is called BPJS institutionally still has some weakness. BPJS institutionally still formality actions and has not touched the substantive justice to promote health security. This research applies empirical model with legal approach, because of the problems studied include aspects of the human mind and regulations. The collected data are arranged inductively by identifying, according to classified the issues and research purposes, then the conclusion that it becomes an ideal model BPJS institutions in order to reach the health security based on substance justice in Indonesia.
\end{abstract}

Keywords Institution, Health Security, Justice

\section{Introduction}

Based on the provisions of Article 1 point (6) in conjunction with Article 5, verse (1) of the Law of Indonesia Number 40 of 2004 on National Social Security System (Social Security Law) that says that Social Security should be a separate legal entity and its formation should be through legislation. Along the way, the above provisions in accordance with the Decision of the Indonesian Constitutional Court Case No. 007/PUU-III/2005 on Judicial Review of Law of Social Security. The Key points of that Decision is Article 5 verse (2), (3) and (4) Law of Social Security does not have binding legal force.

The legal consequences of that Decision gives a legal obligation to governments, namely (1) mandates the establishment of Social Security Organizing Body, and (2) Implement the institutional transformation of PT Askes (Persero), PT Jamsostek (Persero), TASPEN PT (Persero) and PT Asabri (Persero) into the Social Security Institution. The transformation followed by the transfer of participants, programs, assets and liabilities, employees, and the rights and obligations. ${ }^{[\mathrm{i}]}$

The Parliament and the government finally approved the bill of Social Security Administration (SSA) into Law Number 24 of 2011 on the Social Security Administration (Law of SSA) on 28 October 2011. Furthermore, in order to implement the decision Constitutional Court, the transformation of social security institutions is carried out by issuing PT Askes (Persero) and PT Jamsostek (Persero) of the legal order state-owned enterprises Persero to order an autonomous non-profit public entity, namely BPJS. While the two SOEs Limited, namely PT Asabri (Persero) and PT TASPEN (Persero) remains as a body of private pro-profit and subject to the provisions of the Law Number 19 of 2003 on State-Owned Enterprises (Law of SOEs) and Law Number 40 of 2007 regarding Limited Liability Company (Law of Limited Liability Company). This dualism will continue until the transfer of programs and program Asabri TASPEN to BPJS Employment is completed and the total Indonesian population is ruled by the provisions of the Social Security Act at the latest in 2029. ${ }^{\text {[ii] }}$

Institutionally, BPJS is a legal entity that is in accordance with The Social Security Law and the Law of SSA and is not subject either to Law of SOEs and Law of Limited Liability Company, Pursuant to Article 4 (b) Law of SSA, BPJS that in organizing the national social security system carried out by the non-profit principle. This means that BPJS in carrying out the functions and authorities had the principle of business management that prioritizes the use of the results of development funds to provide maximum benefit for all participants and not for profit as a primary goal. Contradiction, in Article 10 (d) in conjunction with Article 11 (b) in conjunction with Article 43 verse (2) letter c Law of SSA, mentioned that BPJS right to manage the Social Security Fund for the benefit of participants in the product short-term investments and long-term, which in activities the main purpose of investment is profit. ${ }^{[i i i]}$ As a public entity 
and shall conduct business activities in the private domain, of course the more confusing. Based on the provisions of Article 47 of the Law of SSA explicitly states that BPJS can not be bankrupted by the provisions of legislation on bankruptcy. Whereas in business activity, the issue of bankruptcy is normal and unavoidable when there is the risk of a mistake in running management (miss-management).

The absence of boundaries between social and economy institutions will certainly make other potential problems arise, among others: First, abuse of authority that can be done by employees, officers, and partners of BPJS Health that may cause Fraud Risk. Secondly, as a non-profit organization, BPJS Health has financial risks such as the potential loss if the total insurance premiums received less than operating expenses and insurance claims that incurred. Thirdly, there is the potential that the contracts are performed BPJS cooperation with other parties (insurance, banking, hospitals, to ministries) emerging potential problems that led to the non-fulfillment of obligations of each party contract until a failure occurs. Fourth, In its business, BPJS Health collects premiums and payment of insurance claims from and for participants. Total premiums that collected and the total amount of claims that appear to have a different nominal value each period. This raises the possibility of a mismatch between the premiums and the value of the claim in a certain period. If BPJS Health does not have sufficient liquid assets in each period, they can lead to failure of compliance with the insurance claim.

Based on those problems, it becomes important to formulate ideal format the institution of Social Security Administration to manage health security's funds in Indonesia.

\section{Method}

This research applies methods of empirical legal research because the data obtained through observations and interviews. Secondary data sourced from a document that is personal and the public, as well as secondary data in the field of law. Collecting discussed with respect to reality collected. ${ }^{[i v}{ }^{]}$Data was obtained from primary and secondary data. The primary data sourced from BPJS office in central Jakarta and Surakarta BPJS office, Public and Health Practitioners and Academics. Secondary data is done through literature and content analysis of documents, archives, legal materials primary and secondary law. The collected data are arranged inductively by identifying, according to classified the issues and research purposes, then the conclusion.

\section{Result and Discussion}

\section{Best Practices}

There is no country in every corner of this world who do not want the welfare of a goal. The goal of the state has change, from the night watchman state to the welfare state. ${ }^{[\mathrm{v}]}$ Welfare then perceived when all citizens can meet their basic need is easy to avoid the risks that threaten their lives. To achieve this goal, one of the duties to be performed by the state is the implementation of social security for each resident in an integrated and comprehensive. ${ }^{\text {[vi] }}$

Implementation of social security, as first pioneered by Otto von Bismarck in Germany in 1883 principally intended as an effort to realize the people's welfare. Today the Social Security System has been growing around the world with various modifications, according to the circumstances, needs and even the political and economic system in each country. ${ }^{\text {[vii }]}$

\section{a) Management of the Social Health Security Funds in Germany}

As an innovator in the modern implementation of social security, it is not surprising that many countries refer to and modify the implementation of the social security system which has been implemented in the Germany since the enactment of the Imperial Decree dated 17 November 1881 on the initiative of thinking of Otto von Bismarck, that called Soziale Sicherheit. At the beginning, the burden of administering social security in the Germany rely entirely to the state based on three main principles: (1) The payment of premiums by the participants (2) The involvement of the State in its investment funds and supervision, and (3) Participation proportional and balanced both participants, employers and governments in making any policy relating to the conduct of social.

Today, the concept of administering social security in Germany metamorphosed towards a better, characterized by the existence of the self-government principle, that releases of state involvement in the management of social security funds. The burden of management and development of the social security funds shifted from the State to the corporate sector, based on public legal entity. This principle requires the active participation of the participants and employers independently without involving the state in the management and development of social security funds. State's role is reduced merely to control the course of the management and development of social security funds in accordance with legal regulations. The implementation of state supervision in the administration of social security in Germany carried out by the Ministry of Health (Bundesministerium für Gesundheit) for social labor security, and the Ministry of Labor and Social Affairs (Bundesministerium für Arbeit und Soziales) for social health security.

b) Management of the Social Health Security Funds in England

Escalation of the labor movement in England in the early twentieth century has shed new light about the importance of the state to make social policies that are pro-people. After experiencing a long debate under the liberal government of Herbert Asquith at that time, the British Parliament finally 
releasing The Old Age Pensions in $1908 .{ }^{[}{ }^{[}$viii ${ }^{]}$Then three years later appeared regulatory its coverage more widely known as the National Insurance Act of 1911. The birth of this regulation inspired after David Lloyd George (the Finance Minister of the United Kingdom in the era of Herbert Asquith) visited to Germany in 1908. A year later, David Lloyd George, gave a statement that England should align with the Germany not only in armaments but also social welfare.

National Insurance Act 1911 gives to the working class in England to contribute into the insurance system to protect their rights (when sickness or unemployment). The regulation is also a milestone in the history of the birth of the concept of social security in England. Dalam journey, National Insurance Act 1911, has undergone several adjustments to the Amendment in the framework of political conditions in the United Kingdom. The management of social security controls in the UK are run under the Ministry for Work and Retirement for social security to labor, and the Ministry of Health through the National Health Service (NHS) for social security health.

Recent regulation in the UK is The Health \& Social Care Act 2012. The UK has been named by The Commonwealth Fund agencies to be the best country that has a social security system compared with ten other developed countries (Australia, Canada, France, Germany, the Netherlands, New Zealand, Norway, Sweden, Switzerland and the United States) in providing health services through the NHS. In addition to known publicly funded healthcare system, NHS collecting funds with the premium offered by the government through taxes paid by residents. British government is in full control in the administration of social health security.

c) Management of the Social Health Security Funds in United States of America (USA)

The management of social security in the United States is fronted by an independent agency, namely the Social Security Administration (SSA). Institute for the Social Security Administration (SSA) is formed by recourse provisions of the Social Security Act after the US experienced a severe economic depression shocks in 1930. Initially, the SSA program is intended only for servicing pension payments (retirement benefts and only to the worker) to the population aged 65 years or older. ${ }^{[i x]}$

SSA is an independent agency headed by a commissioner chosen by the President and must be approved by Congress. The responsibility of the commissioner include development of policies, directives administration and programs, interpretation and evaluation of the program, maintenance of relationships with the news media, research-oriented studies on issues economic insecurity in society and development to promote social security and economy through social insurance and some related programs. During its development, the Social Security Act was recorded has undergone several amendments with the aim of adding a service program tailored to the demands and needs of residents of the United States. During the reign of President Lyndon Baines Johnson in 1965, the Social Security Act was amended by the addition of health care programs (Medicare and Medicaid). ${ }^{[\mathrm{x}]}$

SSA, in the management of social security funds health involves two fundamental elements, namely the collection of funds and portfolio diversification. Fundraisers are fundraisers social security premium payments derived from taxes, included social security funds, while portfolio diversification is the social security fund development activities that have been collected through the social security trust fund. Portfolio diversification businesses use the services of an investment firm that is selected by the selection super tight. ${ }^{[\mathrm{xi}]}$

\section{The Ideal Models of BPJS Health Institutional}

BPJS Health has an important role in ensuring the future health of the people of Indonesia.The institutionally of SSA/BPJS is different to the insurance agency. Insurance agencies entirely economic institutions, while the basic concept of BPJS is a social institution. However, in the implementation of its business, the principles BPJS almost similar to the insurance agencies that depend on the activities from premium payments of the participants. Therefore, in BPJS there is a transfer of responsibility from the state to the individual or the people through fees paid directly, or through private employers to employees, or by the state for civil servants. In addition, residents will receive their social security is the one that recorded to pay dues as participants while the citizens who did not, will do not receive.

Article $28 \mathrm{H}$ of the Constitution of the Republic of Indonesia, which states that everyone has the right to live physical and spiritual prosperity, reside, and get a good environment and healthy and receive medical care. Article 34 verse (3) stated that the State responsibles for the provision of health care facilities and public facilities viable. Based on those Articles, Indonesia adopts welfare state, namely the state guarantees the welfare, including health of its citizens. State has to responsible for the management of these guarantees made through BPJS Health. These responsibilities should ensure operational and continuity of the SSA institutions.

In the insurance business involves 4 (four) institutions namely; participants, insurance companies, hospitals or health institutions and business corporations. While in BPJS institutions, involves five (5), namely: participants that citizens of Indonesia, BPJS Health as manager of a health insurance program, health institutions (hospitals, health centers or clinics), the state as a responsible institution program at once as a regulator, and the business corporation to manage the placements of insurance premiums to reach benefit for BPJS institutions. BPJS Health involves the state, because BPJS is formed by the state as the Constitution of Indonesia mandate.

The bill of The Law of SSA in Indonesia actually clone/imitating the implementation of SSA in the United States. However, in the development of social security funds 
health found the principal difference between the two. The independence and authority of SSA in America much different from BPJS in Indonesia. BPJS somewhat embarrassed to imitate the whole concept of SSA in the United States. Despite the issuance of Government Regulation Number 87 of 2013 on the Management of Assets Social Security Fund of Health, but in the provision of these rules only regulate the products investments that may be used in the development of social security funds health, while setting the procedures and mechanisms for the selection of an investment company as well as the mechanisms profit-loss distribution of the social security fund development activities are not regulated. Within the framework of the development of social security funds health oriented to the welfare of the participants, the following can be submitted several alternative institutional models, among others:

\section{a) Public-Private Partnership}

Public-private partnership is a long-term contract between a private party and a government agency, for providing a public asset or service, in the which the private party bears significant risk and management responsibility ${ }^{\left[x_{i i}\right]}$ As a treaty-based relationship between government and the private sector in public service delivery, public-private partnership can be used as a model institution in the framework of the development of social health security funds.

Johannes Jütting stated that the use of models of public-private partnership in the management of social security is particularly useful in developing countries. In general, in developing countries (including Indonesia) competence and expertise of human resources owned by the government as the main actor, managing unstandards, therefore they need partnership with the private sector which is believed to provide support to the government. ${ }^{\text {[xiii] }}$

The author argues that this model is more flexible to be applied without much change from the regulatory side. Briefly models of public-private partnership can be explained by this figure.

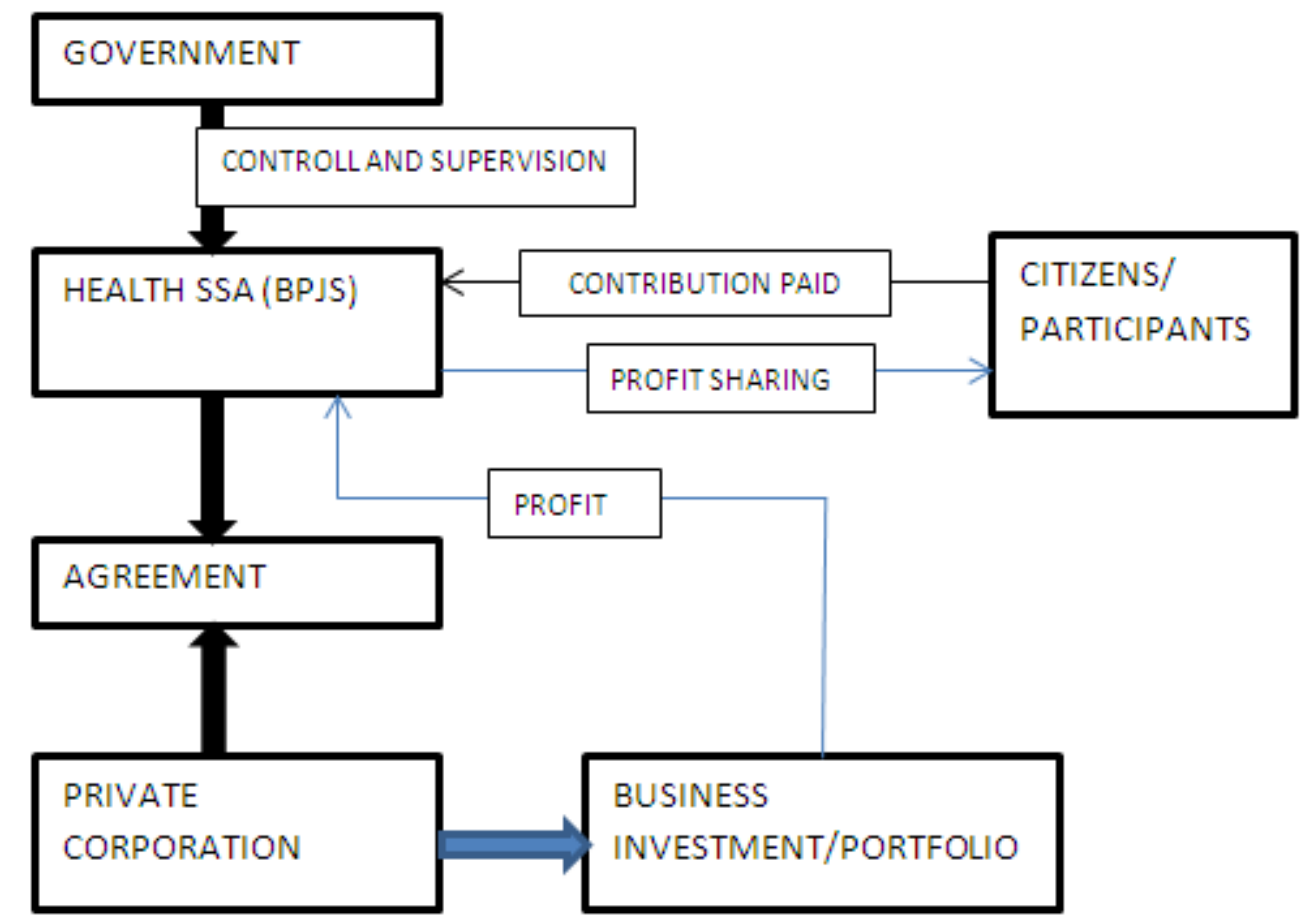

Figure 1. Public Private Partnership Model 


\section{1) Agreement Limitation}

Agreement limitations are limitations on investment products are allowed and which are prohibited to be developed by the company/private corporation. Private Corporation selected by the tigh process, voted in developing social health insurance fund is obliged to follow all the terms of the agreement signed with the BPJS directors. Agreements were made, contains of the financing mechanism chosen investment company/private corporation, investment product and the dispute settlement mechanism.

\section{2) Government}

Government, through an organ that oppointed has authority to control and oversee the operational of BPJS. As a public agency, controlling and supervision should be held by the Health Ministry or Social Ministry. But actually if BPJS operating as a private agency to reach the profit goal, so Financial Services Authority should be involved.

\section{3) Redistribution the profit to participants}

The contribution from the participants is used by BPJS to get benefits, namely : public/health services and profit. The results of the development of that contribution from private corporation is profit that should be distribute equal and fair to all the participants.

\section{b) Establishment of Trustees}

Based on Article 4 of the Law of Social Security, one of the implementation principles of Security System anchored in the principle of mutual/trust fund which means that the funds collected from participants' contributions is entrusted to agencies organizers to be managed as well as possible in order to optimize the fund for the welfare services for the participants. This concept is in accordance with Article 34 of the Constitution, due to the implementation of social security responsibility fully borne by the government. The concept of trustee institutions has actually been growing in Europe during the Middle Ages as "mutual benefit societies" where its formation was based on religious fraternity (brotherhoods), economic or social (H Thabrany, 2009: 36 ). In Indonesia, the concept of the trustee institution also has long been run by our society as a social gathering, jumputan (Java), Subak (Bali), and others. Briefly this models can be explained by this figure.

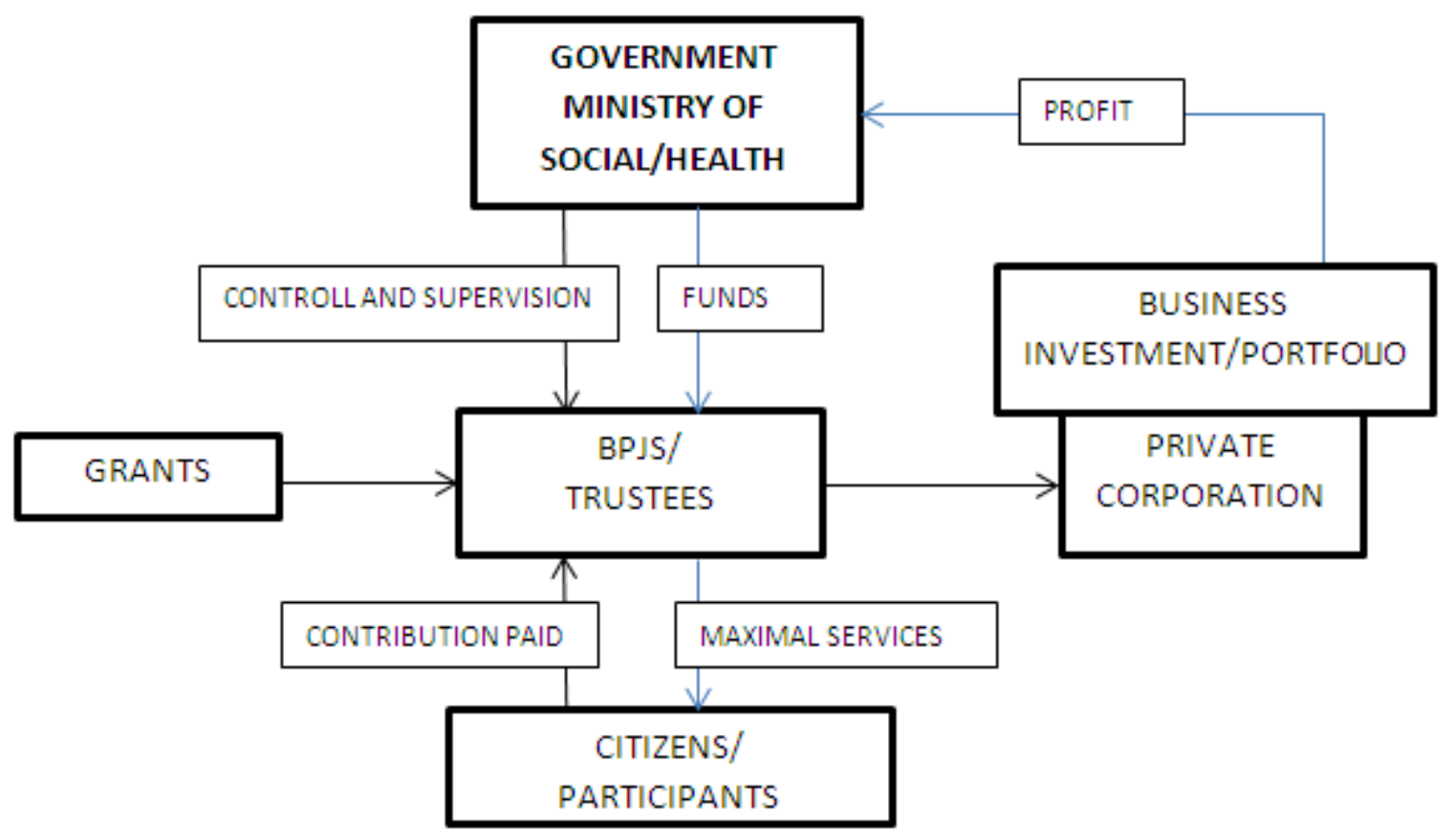

Figure 2. Trustees Model 
In Indonesia, based on that figure above, government need a legal provisions to synchronize and harmonize the regulations related to the changing framework agency, BPJS to be the Trustees Institution. Government has maximal liability for this model. Trustees institution is selected by government. Collecting funds are earned by contribution paid from the partisipants and accept fund from third party as a grant. From this funds, Trustees selected private corporation to manage the fund for getting a profit from some business/investment. The profit result should be give to the government that will be send back to the trustees as a fund or modal to maximize social health services for the participants.

The concept of health insurance for citizens is a constitutional mandate. Has a population of 250 million of people certainly Indonesia is a potential bright business for the health insurance industry. But Indonesia is not only Jakarta, not only Java, but the state that has thousands of islands whose inhabitants are spread from Sumatra to Papua. How can reach people in small islands and secluded is the important one. Most of the good health services, including specialist doctors in Jakarta, whereas for eastern Indonesia (Papua, East Nusa Tenggara, etc) the amount of good health services and specialists are still very minimal. Thus the middle class participants of BPJS Health in Jakarta by paying the same premium to the middle class citizens in Papua, but they get more maximum health services because Jakarta or Java has a better health infrastructure. Of course it can thus lead to social injustice. From the two models mentioned above, the Public-Private Partnership is a more appropriate model, in which the role of government to be a catalyst, to provide incentives and make regulations fair. If the government can not allocate more funding sources for health, then let private participation to deal with groups of people who have been able. While the government focus is directed to the poor or the less party. That way there can be a dual insurance system, insurance for the poor and insurance for the middle/high class.

\section{Conclusions}

The implementation of social security is an absolute obligation (compulsory obligation) of a country as the fulfillment of social rights to every citizen. Within the framework of guaranteeing the implementation of an integrated national security system, integrated and comprehensive legal framework issued by the Law of Social Security and the law of Act and Law of Social Security Institution with its regulations below as translation of the constitutional mandate after the constitution amendment. The institutionally of BPJS has some problems particularly with regard to the management of the development of social security funds. Through this research can be formulated two institutional model of the BPJS in relation to manage and develop of the social health security fund and reduce the weakness, that are a model of Public-Private Partnership and Trustees Institution model. The model is presented along with the advantages and disadvantages of each, may be used as an alternative option in the management and development of social security funds which in turn provide maximum benefits to participants of social security.

\section{Recommendations}

1) BPJS Health has an important role in ensuring the future health of the people of Indonesia. Should immediate synchronize the regulations related to health insurance protection to the citizen.

2) Public-Private Partnership will play an important role. Without the help from the private sector, it will be very difficult to meet the needs of all the citizen. The government must think about how to give a role to the private sector so that they can innovate.

3) The Management of Health on BPJS should prioritize services rather than achieving a profit. The services provided should be framed with professionalism.

4) The code of conduct should be established related to health service procedures in institutional BPJS

\section{REFERENCES}

[1] Dewan Jaminan Sosial Nasional (DJSN), 2014, Paham Transformasi Jaminan Sosial Indonesia, Jakarta: CV Komunitas Pejaten Mediatama

[2] Gordon, Margaret S., 1988, Social Security Policies in Industrial Countries, Cambridge: Cambridge University Press.

[3] Joni, Muhammad, 2005, Menuju Jaminan Sosial untuk Semua dan Pro Poor: Hak Konstitusional yang (masih) Terabaikan diterbitkan oleh Jurnal Mahkamah Konstitusi Republik Indonesia Volume 2, Nomor 3, November 2005, Jakarta: Mahkamah Konstitusi Republik Indonesia.

[4] Jütting, Johannes, 2002, Public-Private Partnerships in The Health Sector: Experiences from Developing Countries, Extension of Social Security (ESS) Working Paper Series No. 10, Geneva: Social Security Policy and Development Branch International Labour Office

[5] Livingston, Steven G, 2008, U.S. Social Security a Reference Handbook, Santa Barbara: ABC-CLIO, Inc.

[6] National Institute of Population and Social Security Research, 2014, Social Security in Japan, Tokyo

[7] Naskah Akademis Rancangan Undang-Undang (RUU) Badan Penyelenggara Jaminan Sosial (BPJS)

[8] O'Brien, Michael, 2008, Poverty, Policy and the state - The Changing Face of Social Security, UK: The Policy Press University of Bristol.

[9] Pemerintah Nomor 87 Tahun 2013 tentang Pengelolaan Aset Dana Jaminan Sosial Kesehatan 
[10] Putusan Mahkamah Konstitusi RI Perkara No. 007/PUU-III/2005 tentang Pengujian Undang-Undang Republik Indonesia Nomor 40 Tahun 2004 tentang Sistem Jaminan Sosial Nasional terhadap UUD Negara RI 1945

[11] Seidman, Laurence S., 1999, Funding Social Security: A Strategic Alternative, Cambridge: Cambridge University Press.

[12] Sembiring, Sentosa, 2010, Hukum Investasi, Bandung: Nuansa Aulia.

[13] Soekanto, Soerjono, 2010, Pengantar Penelitian Hukum. Jakarta: UI Press.

[14] Sulastomo, 2011, Sistem Jaminan Sosial Nasional: Mewujudkan Amanat Konstitusi, Jakarta: PT Gramedia Pustaka Utama. ISocial Security Administration, 2015, The History of Social Security, Baltimore: SSA Publication.

[15] Thabrany, Hasbullah, 2009, Badan Penyelenggara Jaminan Kesehatan Nasional: Sebuah Policy Paper dalam Analisis
Kesesuaian Tujuan dan Struktur BPJS, Posisition Paper bagi the Hatta Project kerjasama antara Perkumpulan Prakarsa dan the Asia Foundation Maret 2009

[16] Undang-Undang Republik Indonesia Nomor 40 Tahun 2004 tentang Sistem Jaminan Sosial Nasional

[17] Undang-Undang Nomor 24 Tahun 2011 tentang Badan Penyelenggara Jaminan Sosial (BPJS).

[18] The World Bank, 2012, Public-Private Partnerships Reference Guide, Washington: The World Bank.

[19] Urbe, Robert, 2012, The Future of The Welfare State (A Compartive Study in EU-Countries), Lambertus-Verlag, Freiburg im Breisgau

[20] Walker, Robert, 2005, Social Security and Welfare Concepts and Comparisons, UK: Open University Press.

$\left.{ }^{[} \mathrm{i}\right]$ Muhammad Joni, Menuju Jaminan Sosial untuk Semua dan Pro Poor: Hak Konstitusional yang (masih) Terabaikan diterbitkan oleh Jurnal Mahkamah Konstitusi Republik Indonesia Volume 2, Nomor 3, November 2005, Jakarta: Mahkamah Konstitusi Republik Indonesia, 2005, p. 16.

${ }^{1 i}{ }^{1}$ Dewan Jaminan Sosial Nasional (DJSN), Paham Transformasi Jaminan Sosial Indonesia, CV Komunitas Pejaten Mediatama, Jakarta, 2014, p. 37. ${ }^{[}$iii $^{\top}$ Sentosa Sembiring, Hukum Investasi, Nuansa Aulia, Bandung, 2010, p. 32.

${ }^{[i v}{ }^{j}$ Soerjono Soekanto. Pengantar Penelitian Hukum, UI Press, Jakarta, 2010 , hlm. 43 .

$\left.{ }_{[\mathrm{V}}\right]$ Robert Urbe, The Future of The Welfare State (A Compartive Study in EU-Countries), Freiburg im Breisgau, Lambertus-Verlag, 2012, p. 9.

${ }^{[} \mathrm{vi}^{]}$Michael O'Brien, Poverty, Policy and the state - The Changing Face of Social Security, The Policy Press University of Bristol, UK, 2008, p. 1-4.

${ }^{[}$vii $^{1}$ Sulastomo, Sistem Jaminan Sosial Nasional: Mewujudkan Amanat Konstitusi, PT Gramedia Pustaka Utama, Jakarta, 2011, p. 25.

${ }^{[}$viii $^{1}$ Margaret S. Gordon, Social Security Policies in Industrial Countries, Cambridge: Cambridge University Press, 1988, p. 27.

[ix ${ }^{]}$Social Security Administration, The History of Social Security, SSA Publication, Baltimore, 2015, p. 1-10

$\left.{ }^{[}\right]^{]}$Robert Walker, Social Security and Welfare Concepts and Comparisons, UK: Open University Press, 2005, p. 63.

${ }^{[x i}{ }^{1}$ Laurence S. Seidman, Funding Social Security : A Strategic Alternative, Cambridge University Press, Cambridge, 1999, p. 1-10.

${ }^{[} \mathrm{xii}^{1}{ }^{]}$The World Bank, Public-Private Partnerships Reference Guide, The World Bank, Washington, 2012, p. 11

${ }^{[}$xiii ${ }^{]}$Johannes Jütting, Public-Private Partnerships in The Health Sector: Experiences from Developing Countries, Extension of Social Security (ESS) Working Paper Series No. 10, Social Security Policy and Development Branch International Labour Office, Geneva, 2002, p. 1-20. 